\title{
Os sabores e saberes da poesia de Izabel Brandão
}

\section{As horas da minha alegria. BRANDÃO, lzabel.}

Florianópolis: Mulheres, 2013, 126p.

Um mineiro já disse, antes de Izabel, que "chegar e partir são só dois lados da mesma viagem".

Na última página de seu novo livro, As horas da minha alegria,' Izabel Brandão o define, sem rodeios, como um "livro de partidas e chegadas". Mas enquanto Milton Nascimento usa o espaço da estação e a figura simbólica do trem para falar metaforicamente da viagem da vida, o livro de Izabel Brandão é ele próprio uma viagem em que vários atalhos conduzem a lugares e não lugares, como magistralmente identificou Helena Parente Cunha em seu Prefácio.

No entanto, falar de "lugares" pode sugeri a procura apenas por lugares em seu sentido físico, e os poemas de lzabel Brandão vão além. Não é simplesmente de um exílio, de estar ou não estar em terra estranha que falam os seus versos. A trajetória entre a infância e a idade adulta configura-se como uma busca de respostas a indagações bem menos simples que as diferenças - a maioria delas, afinal de contas, naturais e esperadas - entre as duas fases da vida. Ao contrapor as pequenas e singelas alegrias de sua infância a uma realidade que, ao longo da vida, nem sempre se mostra tão prazerosa, a autora ultrapassa a temática memorialista, a simples recordação, criando uma poesia que questiona o rumo tomado pela humanidade em tempos atuais, embora o faça de forma leve e, muitas vezes, disfarçada, como é próprio do texto poético.

Certamente, podemos considerar que as imagens da infância rememoradas poeticamente por Izabel passam pelo filtro do tempo, o que significa que a imaginação pode ajudar as lembranças, adornando-as com o que elas têm de melhor. E esse passado, recordado saudosamente em seus recortes mais felizes, mostrase assim como uma razão irrefutável para que a viagem pelo mundo - literal e metaforicamente falando - pareça ainda mais difícil, uma vez que os lugares encontrados e o tempo vivido não correspondam sempre ao que foi deixado para trás. Daí o sentir-se exilada, física e emocionalmente.

Mas como a poesia é, antes de fudo, um texto aberto a múltiplas leituras, leio nos versos da poeta mineira-alagoana uma proposta bem mais sutil na comparação entre o passado e o presente. Como disse anteriormente, a viagem de lzabel passa por muitos atalhos, os quais nem sempre conduzem a respostas claras. E esses atalhos estão na linguagem, camuflados nas palavras com as quais constrói sua poesia. Vejamos, pois, como se dá nos poemas essa comparação entre passado e presente, nem sempre explicitamente apresentada. E para isso a própria estruturação do livro já nos aponta caminhos.

O livro é dividido em quatro partes. Na primeira, "Minas", predominam as lembranças, em poemas que situam a infância e suas imagens num contexto em que a alegria, a felicidade são as principais referências, embora haja poemas que fogem a isso. A fidelidade à sua proposta estética evidencia-se no título dado por lzabel à segunda parte: "Esquinas". Toda esquina esconde algo depois de sua curva. Ao mesmo tempo, esquinas são espaços onde se cruzam caminhos diversos. E os poemas desse segmento trazem um agrupamento semântico bastante significativo: trilhas, rumos, encruzilhada, espinhos... Nessas esquinas se concentram as impressões, descobertas, realizações, sofrimentos do percurso a partir da saída de Minas - representação da infância, da segurança, das certezas. Na terceira parte, "Mundo", a homenagem a seus poetas queridos é a confirmação de que, nessa longa viagem em busca de respostas, a literatura, a poesia representam para Izabel um universo em que a realização é possível.

No poema "De braços com Clarice", uma nova afirmativa dessa relação poesia/vida: "Assim eu abraço as palavras / como quem arruma um novo amor". Entretanto, apesar da intenção dessa terceira parte, a ideia da literatura como um caminho paralelo a auxiliar a vivência do caminho árduo que é a viagem pela vida real já se antecipava na segunda parte. O poema "Incorporação" diz isso sem rodeios:

Não faço versos

apenas para brincar 
com as palavras

o veio delas me abre a porta e

eu vejo mundos

$[\ldots]$

Apenas penso mundos

todos no papel

e é assim que sei falar

pra quem quiser

me ouvir

ou ler.

A última parte é a chegada: a um lugar, a um porto, mesmo que não seja o lugar ideal. Mas esse lugar é "A casa no exílio", com todo peso semântico e simbólico da palavra CASA. Alternam-se nesse segmento os poemas com títulos que falam de exílio e porto. E na página final - um poema quase prosa ou uma prosa quase poema? - explicitam-se todas as dúvidas e certezas, mesclam-se passado e presente, nas alusões às montanhas de Minas e ao mar desse novo porto. E, sendo assim, diz o eu poético: "Por que não aportar?".

Como se pode perceber, há coerência entre a proposta poética e a forma como o livro foi estruturado. A divisão em partes, seus títulos nada mais são que a maneira lírica como Izabel desnuda seu itinerário em busca de lugares, em busca de respostas, as quais nem sempre vêm ou são satisfatórias. Mas o que importa são as vivências da viagem, o que ela diz claramente: "Ainda sem lugar, eu ando".

Porém, se há uma evidente sequenciação entre as diversas partes do livro - que pode ser lida como semelhante à sequência da vida -, nem sempre algumas associações entre essas partes podem ser percebidas de imediato. Anteriormente falei na comparação entre passado e presente como algo que sutilmente a autora propõe ao longo de seus poemas. Não que essas comparações não estejam claramente postas em muitos desses poemas. Mas as há menos explícitas. É dessas associações que irei falar em seguida, mais especificamente em relação às duas primeiras partes do livro.

O poema "A casa de minha infância", da primeira parte, exemplifica muito bem o universo de lembranças que a própria persona poética reconhece como "adoçadas" (verso 2). Cabe salientar que o termo "adoçados", que poderia apresentar uma conotação depreciativa, na verdade introduz, por estar logo no início do poema, o que considero uma característica marcante dessa parte inicial da obra: o uso de termos que poderíamos dizer que estão relacionados a uma "semântica do sabor", na falta de outro termo que melhor expresse essa abundância de expressões ligadas a alimentos ao longo não apenas desse poema, mas de todo o livro, e de forma mais recorrente nessa primeira parte.

"Comida", "doces", "uvas", "mangas", "pitangas", "pinhas" são palavras encontradas nesse poema. Nada demais nessa alusão a alimentos, a sabores, não fosse o fato de eles virem misturados em versos nos quais, por exemplo, o eu lírico narra que sua avó "olhava tudo com olhos de dona - a comida, os filhos, / os doces, os netos, a política de interior", igualando afetivamente nesse TUDO elementos tão distintos, tais como pessoas queridas, comidas (colocada separada de doces!!!) e política.

Outro agrupamento significativo no poema são as palavras que, de alguma forma, remetem à ideia de felicidade, de beleza, encabeçadas, como já citado, por "adoçados"; "dia de festa"; "casa linda"; "jardim em flor"; "pingos de alegria"; "bom humor"; "olhos de amor".

Também se mostra relevante a nomeação de pessoas, o que nunca acontece isoladamente, mas sempre associada a alguma ocupação ou a alguma atitude delas - ou às duas coisas juntas. "Seu João vigiava a rua"; o "bumba de Gusta / acordando a cidade inteira em dia de festa"; a avó, que cuidava da palmeira da rua "como se fosse sua"; a "lavadeira Torquata" ditando cartas; "a cozinheira Virgínia", de quem se destaca seu "bom humor"; "Sá Lau da Estiva", preta que, além dos "olhos de amor", trazia "doces dentro da trouxa" (mais uma vez amor e doces juntos!). Citam-se, ainda, Fia, Alzira, Preta e Vita e, em outro poema, Quelé da Ladeira.

Ainda em "Minas" há dois poemas dedicados à Preta. No "Preta l", é descrita uma tia Pretinha "alegre, risonha, feliz", que "contava histórias". E a saudade dela era "do abraço gorducho / da panela de arroz raspado / com farinha e gordura e do gosto da carne / de sol mordida com gosto". Atente-se para a associação, mais uma vez, entre felicidade e alimento. No poema "Preta II", essa associação continua, e "histórias temperadas / colhidas na colher de pau sobre o fogão / - arroz com farinha e gordura / panela de barro, pimenta e feijão" aparecem misturadas a recordações de contos infantis. E o eu lírico encerra o poema falando numa "infância com gosto de farra e temperada de alegria" - novamente o uso metafórico da "semântica do sabor".

Em outra estrofe, o eu lírico, num inusitado processo sinestésico, usa o adjetivo "suculentas" 
para qualificar as "horas de alegria", além de valer-se de "romãs maduras e vermelhinhas" para compor essa "imagem" da alegria.

\section{[...]}

Assim o peso da vida vira pluma ao vento

e o cheiro transparente e puro

das romãs maduras e vermelhinhas tornarão eternas e suculentas

as horas da minha alegria.

Em outro poema metalinguístico, "Seda e espinho", a palavra é "fruta amarelo-ouro / colorindo o corpo / por dentro". Para falar da vida, uma belíssima metáfora, mais uma vez recorrendo aos sabores: "[...] a vida [...]/ é remédio bebido no chá do esquecimento / quando a dor no peito é grande" ("Biografia familiar").

Se insisto em apontar tais ocorrências estilísticas na poesia de Izabel Brandão é porque as vejo como parte do caminho poético trilhado por ela, como um recurso significativo usado na construção e sequenciação dos poemas que compõem este livro.

No poema "Pedaços de sonhos velhos", já na segunda parte do livro, o eu lírico utiliza-se predominantemente de palavras relacionadas ao ato de costurar: "Costuro um pedaço de sonho velho". E na continuação encontramos "o bater da máquina de costura", "sonhos puídos", a poesia que se desfaz quando se fura "o dedo na agulha", e o "fuso mostrando o real". Entretanto, em sua penúltima estrofe, a volta ao mesmo universo semântico dos poemas já citados:

Desfaço os pontos de sonho. Melhor ir almoçar porque a mesa está posta

e o feijão ferve na panela. A vida anda.

- Ande também, diz a voz de mim, calando o fastio da morte que ronda minhas esquinas.

[...]

É digno de menção o uso do grau comparativo - MELHOR - como demarcação dessa passagem do universo semântico da costura para o dos alimentos. Este representa a realidade, à qual o eu lírico volta após se "desfazerem os pontos dos sonhos". Afinal, "A vida anda", e o inevitável cotidiano conduz à rotina da mesa posta e do feijão na panela. E numa interessante construção linguística, a persona poética coloca antiteticamente a vida - presente no feijão que "ferve na panela" - e o "fastio da morte", reforçando a ideia da associação entre alimento e vida e, por que não dizer, entre alimento e felicidade, pressentida principalmente na primeira parte do livro. E a alusão a "esquinas" no contexto desse poema, no seu $5^{\circ}$ verso, ratifica a proposta estrutural do livro, já comentada anteriormente.

Todavia, a coerência com que Izabel Brandão dividiu seu livro, agrupando seus poemas em quatro (4) partes, tem mais um ponto digno de registro. Refiro-me aos quatro últimos poemas da sequência "Esquinas". Não parece aleatória a sua colocação como arremate de uma parte do livro que, como eu já disse, prioriza a reflexão, na busca por explicações e respostas. Refiro-me aos poemas "Sinal de trânsito", "O filho da rua", "Canção para o menino que dorme" e "Almas tristes".

Se nos poemas anteriormente citados o feijão aparecia como um sinônimo do alimento cotidiano sempre presente, nos versos de "Sinal de trânsito" aparece como fonte de sobrevivência para as crianças "que andam pelos sinais / No trânsito lento". O poema fala de um "Menino sem lar [...] vendendo feijão", e nele o feijão é apresentado em "verdes grãos", e numa alusão cromática, esses verdes grãos estão em "mãos expostas, olhando o céu / em esperançoso agradecimento". O cromatismo não é gratuito, haja vista a oposição entre o feijão verde, remetendo, ambiguamente, ao "esperançoso agradecimento", e o "sinal vermelho" em que se encontra o menino. Esperança $X$ alerta, perigo?

O poema "O filho da rua" fala de uma jovem mãe com seu filho no colo, na rua, sob a chuva Repetem-se nela, mesmo que de forma menos explícita, as alusões à fome a ao alimento. $\mathrm{Na} 1^{\mathrm{a}}$ estrofe, "A fralda molhada que lhe cobre o corpo / esfria a fome do estômago". Na estrofe seguinte, um jogo semântico de impacto: "As feras da rua olham o corpo da jovem mãe / e querem comêla viva / o bebê é sobremesa na rua escura". Saliente-se o uso do verbo comer, em seu sentido pejorativo, dúbio, e da palavra "sobremesa", ambos reiterando a manutenção do campo semântico ligado a alimento, num contexto absolutamente diferente daquele usado anteriormente. Adiante, a referência a estômago é associada ao medo - "o medo na boca do estômago" de "leões soltos pela rua". E desta vez é o "menino do feijão verde" que "chama a mãe e bebê para perto de si / ergue os olhos e agradece à 
alma da rua que the escorregou a moeda na mão". E o menino é apontado como um "pequeno gladiador", que "veste a roupa da rua". E numa recorrência à ideia de continuidade da vida inúmeras vezes citada ao longo dos poemas, "é nele [o menino] que a vida deve seguir".

Um cenário diferente para uma realidade semelhante aparece no poema "Canção para o menino que dorme". Esse cenário é um hipermercado, templo do consumo, da exposição variada de alimentos ao alcance da mão. Nele um menino dorme e sua "barriga de fome aperta o frio / piso do hipermercado". O menino dorme "entre as gôndolas de informática", entre "computadores / que nunca [vai] ter". À fome real acrescenta-se a fome de esperança de um futuro de progresso e de tecnologia do qual ele está excluído: "Onde a vida anda / tu não estás, menino".

Encerrar a segunda parte do livro com poemas de cunho social, expondo a realidade de crianças de rua, sem lar, sem alimento, sem afeto, solitárias em sua luta pela sobrevivência, evidencia claramente a proposta da autora de expressar o contraste entre o passado, a infância narrada na primeira parte, com sua fartura de alimento e afeto, e a realidade do presente, com a qual a autora se depara nas "esquinas" por que passa em seu trajeto em busca de lugares e de respostas.

A casa que tinha "as cores dos [...] sonhos", a "casa linda, na esquina, de sacada e varanda e jardim em flor", com quintal, frutas, presente no poema "A casa de minha infância", contrasta com as "casas de luto / cobertas de preto plástico / sobre a terra crua" descritas no poema "Almas tristes", que fecha a segunda parte do livro.

Um outro aspecto dessas comparações pode ser percebido em dois poemas: "Modernidade etc. e tal", presente em "Esquinas", e "Facebook", o único da terceira parte que incluo nessa oposição entre passado e presente.

Foram citados anteriormente, como um aspecto merecedor de menção nos poemas situados na primeira parte do livro, nomes de pessoas, que sempre aparecem associados a lembranças de afeto e convivência. Em oposição a isso, o poema "Modernidade etc. e tal" fala de

\author{
[...] pessoas \\ que não se veem \\ ou se telefonam \\ apenas mandam e-mails.com
}

\section{E conclui:}

O prazer perdeu a graça.

Não tem sintonia alguma

Apesar de ligado e a mil.

Perdemos o fio?

Ou o fio é o pavio?

De forma indireta, a poeta coloca em oposição o passado, quando as pessoas conviviam com simplicidade, onde havia a comunicação mais direta e a proximidade física, e um presente, em que, apesar de se dizer que vivemos na era da comunicação, as pessoas "não se veem".

Essa ideia de solidão relacionada ao tempo presente fica mais nítida no poema "Facebook". Para o eu lírico, essa forma de comunicação é apenas "Um álbum de recortes", que "vê quem quer / se quer". E assim,

\author{
[...] não há laços \\ nem abraços \\ apenas a porta de um universo \\ invisível \\ perdido \\ [...]
}

Não há como não associar ao "abraço gorducho" da tia Pretinha!! E o eu lírico interroga: "Há amigos?".

E num jogo gráfico-semântico - "solict/ d)ários" - fica evidente o questionamento proposto: o ser humano atual é realmente solidário, comunica-se, ou é apenas um solitário?? A resposta parece estar nos últimos versos do poema, em que a persona poética simplesmente cita a "solidão da net".

Os exemplos aqui transcritos falam por si mesmos. A estrutura dada ao livro e a escolha lexical de lzabel na construção dos poemas que compõem As horas da minha alegria demonstram a maturidade de uma poeta consciente de sua proposta poética, daí a coerência estrutural e ideológica percebida no livro. A opção por um universo semântico que se aplica a várias situações, em associações muitas vezes inusitadas e inesperadas, mostrou ser um recurso criativo e muito próprio da poeta, quase que uma marca dessa obra, proporcionando aos leitores momentos de grande beleza poética. $E$ não deixa de ser uma opção ousada em 
termos literários, uma vez que recorrer a metáforas ligadas ao campo semântico do alimento poderia não resultar em construções estéticas tão especiais como se vê ao longo dos poemas.

Vale a pena encerrar esses comentários com um poema bem significativo, em que a autora se situa em seu presente, apresentandose como uma mulher atual, conectada com sua realidade. O poema intitula-se "Autobiografia".

Tempero pronto é para mulher preguiçosa

- eu sou uma delas...

Meu fogão é o computador

os livros, as panelas

as canetas são colheres

e os pratos, os papéis onde escrevo/como

poemas

críticas

extensões do meu pensar as receitas cotidianas

que esqueci de anotar.

Este seria apenas um interessante poema autobiográfico, não fosse o fato de reiterar, de forma inequívoca, num estilo leve e gracioso, a proposta estética e lexical que permeia a maior parte do livro e mostra um estilo bem pessoal de Izabel Brandão nessa obra: a sua opção por uma terminologia ligada ao alimento, à comida. Nele as alusões a tempero, fogão panelas, colheres e pratos, associadas a computador, livros, papéis e textos - suas "receitas" de literatura -, estabelecem a ligação entre passado e presente fazendo uso do mesmo recurso escolhido pela autora para falar de seus caminhos, de suas buscas, de seu percurso existencial. E mais que isso, significam o pensamento coeso e a qualidade estética de uma poeta amadurecida, pronta para novas "alegrias" literárias.

\section{Nota}

${ }^{1}$ Florianópolis: Mulheres, 2013.

Maria Heloisa Melo de Moraes Universidade Federal de Alagoas 